\title{
In steady search for optimization: the role of public and private actors in Switzerland's political economy of adult education
}

\author{
Michael Geiss (D)
}

Received: 30 January 2020 / Accepted: 24 April 2020 / Published online: 11 May 2020

(C) The Author(s) 2020

\begin{abstract}
This article reconstructs the changes in the political economy of adult education in Switzerland since the middle of the 20th century. Methodologically, the analysis is based on historical institutionalism and concentrates on path dependencies and critical junctures. It is shown that the Swiss adult education system is neither exclusively a marked-led nor a stakeholder-led regime. Instead, it is demonstrated that the current situation cannot be understood without considering the several government initiatives in the context of digital change since the 1970s as well as the efforts of the private national continuing education association SVEB. The article concludes with reflections on the expected impact of the first national law on continuing education which has been enacted in 2017.
\end{abstract}

Keywords Market $\cdot$ Corporatism $\cdot$ Switzerland $\cdot$ Stakeholder $\cdot$ Legislation

Dr. M. Geiss ( $\bowtie)$

Institute of Education, Education and Work Research Unit, University of Zurich, Zurich, Switzerland

E-Mail: mgeiss@ife.uzh.ch 


\section{Auf der stetigen Suche nach Optimierung: Die Rolle der öffentlichen und privaten Akteure in der politischen Ökonomie der Erwachsenenbildung in der Schweiz}

Zusammenfassung Dieser Artikel rekonstruiert die Veränderungen in der politischen Ökonomie der Schweizer Erwachsenenbildung seit Mitte des 20. Jahrhunderts. Methodisch stützt sich die Analyse auf den historischen Institutionalismus und konzentriert sich damit auf Pfadabhängigkeiten und sogenannte „,critical junctures“. Im Folgenden wird gezeigt, dass die Entwicklung des Weiterbildungssystems in der Schweiz weder allein korporatistischen noch ausschließlich Marktprinzipien folgt. Vielmehr wird gezeigt, dass die gegenwärtige Situation nicht ohne Berücksichtigung der verschiedenen nationalen Initiativen im Kontext des digitalen Wandels seit den 1970er Jahren sowie der Arbeit des Schweizerischen Verbands für Weiterbildung SVEB verstanden werden kann. Der Artikel schließt mit Überlegungen zu den erwarteten Auswirkungen des ersten nationalen Weiterbildungsgesetzes, das 2017 in Kraft getreten ist.

Schlüsselwörter Markt $\cdot$ Korporatismus $\cdot$ Schweiz $\cdot$ Stakeholder $\cdot$ Gesetzgebung

\section{Introduction}

In comparative research, adult education in Switzerland is considered either as part of a collective skill formation system with a strong role for business associations or it is stressed that supply and demand in general and vocational continuing education is regulated by the market (Desjardins 2017, pp. 25-31). This article deals with these contradictory accounts of the Swiss adult education system. It reconstructs path dependencies and critical junctures in the institutional development of adult education in Switzerland. It depicts the ongoing power of the employers, industry and professional associations, and the liberal-minded national authorities in Switzerland. It also shows that several other corporate actors played an important role in more recent developments too. These include the national continuing education association (SVEB) and single education providers like the private so-called Migros Club Schools, and in one important instance even the Swiss trade unions to which a weak role is usually attributed in the Swiss political economy (Bonoli 2019).

The following analyses concentrate on the national level and mention cantonal developments only where they complement the picture in a decisive way. Methodologically, the article follows the approach of historical institutionalism. The focus is put primarily on political developments. This is not the only possible perspective on the development of adult education. However, a reconstruction based on participation rates or finances is not possible due to a lack of data for most of the 20th century.

The state of research, the methodological approach and the data are discussed in the first section (2). The next step is to describe the relationship between vocational and general adult education up to the late 1960 s and to introduce the key players (3). 
A significant shift was then initiated with the two oil crises in the 1970s. The state invested in research, development and qualifications in the field of new technologies, which also had consequences for vocational and even general adult education (4). At the same time, the national umbrella organization for adult education reorganized itself in several steps and developed highly formalized instruments for professionalizing and consolidating continuing education (5). From here it was not a big step to a law on continuing education which was enacted in 2017 (6).

\section{State of research and methodology}

By international comparison, participation in continuing education and training can be regarded as very high (SBFI 2019). However, in comparative research on the political economy of adult education the Swiss case is characterized very differently. In 2003, an OECD report on post-secondary education in Switzerland concluded that Swiss continuing education was primarily based on market principles and that the state's claims to regulation were generally rejected (OECD 2003, p. 92). Weber and Wittpoth also stress the role of private providers and trace the repeated failed attempts since the 1970s to regulate adult education at the federal level. At the same time however, they show how an increasing state involvement was observed at the cantonal level. Weber and Wittpoth explain the much more cautious policy of continuing education compared with Germany by the fact that Switzerland has never had a social-democrat-oriented administration through the all-party government (Weber and Wittpoth 1999; Weber 2007).

Taking these ambiguities into account, it is not surprising that the Swiss system can be characterized as a market-led regime, but is also clearly conservative and corporatist. Desjardins has pointed out that, depending on the analytical perspective and weighting of different factors, countries can be assigned to different types of nobility and there are hybrid forms (Desjardins 2017, pp. 25-31). Last, but not least, the interpretation of the Swiss case depends on the extent to which both general and vocational adult education are considered. If only vocational continuing education is taken into account, Switzerland appears as an example of the type of "coordinated market economies" (CME) with a strong tradition of "collective skill formation" (Rees 2013, p. 203; Busemeyer and Trampusch 2012). Even specialized analyses have not changed this picture: Trampusch and Eichenberger have shown that the reluctance of the Swiss state authorities in the area of adult education is partly counteracted by their willingness to declare the collective labour agreements binding (Trampusch and Eichenberger 2012).

Overall, it must be conceded that research on adult education has never been established at Swiss universities. It is being promoted by the national continuing education association SVEB, often in cooperation with individual researchers from various academic disciplines. This is reflected last but not least in the fact that research in Switzerland focused on very particular subjects or questions. In order to understand the Swiss political economy of adult education, it is not sufficient to concentrate on continuing vocational education (CVET) alone or to stress the role of private schools. The picture would not be complete without mentioning the 
almost uncoordinated interplay between the federal state boards and the SVEB. It is also essential to give appropriate recognition to the role of one private provider, Migros Club Schools, which is cross-financed by a giant supermarket chain and retail company (Geiss 2016; Schläfli and Sgier 2008).

While most presentations on the structure and governance of adult education in Switzerland argue rather statically, the focus of this article is on institutional change. The analysis thus follows the approach of historical institutionalism, focusing on the genesis and stabilization of institutional arrangements on the one hand, and at the same time asking about certain points in history where fundamental change became possible (Thelen and Steinmo 1992; Capoccia 2016).

There are some restrictions associated with the methodological approach applied here. Developments in individual economic sectors or specific areas of adult education must be neglected in favour of a coherent picture. Historical institutionalism also tends to overemphasize national developments and to lose sight of entanglements and transnational phenomena (Peck and Theodore 2007; Jessop 2011).

My sources include government reports, legal documents, thematic brochures, publications of associations and historical newspapers or journal articles. These are analysed in order to determine which actors expressed themselves at different points in time and what were their demands. In addition, I have evaluated previous analyses of the political economy of skill formation and continuing education policy in Switzerland.

\section{Adult education in Switzerland before the oil crises}

To understand the political economy of adult education in Switzerland, a sharp distinction must be made between continuing vocational education and training and all other fields of adult education. The former was already mentioned in the first National Vocational Training Act of 1930. The law wanted CVET to remain a voluntary matter, but established the eligibility of this area for subsidies. This applied not only to the preparation for the master craftsman's examination in the manual trades, but also to other courses (Schweizerischer Bundesrat 1928, 1932, Art. 50e). CVET was further strengthened with the first revision of the law in 1963. The main arguments used here were the noticeable shortage of skilled workers on all sides, rapid change and increasing specialization (Schweizerischer Bundesrat 1962). Until the end of the century, non-vocational adult education remained in the responsibility of the individual cantons and civil society initiatives. The financial support of adult education by the Federal Government was only possible to a limited extent and only via the detour of cultural policy and other auxiliary constructions (Geiss 2016).

In the middle of the 20th century, the Swiss adult education landscape was more or less settled. On the CVET side, cantons, vocational schools, training workshops, technical schools, professional associations and single providers all offered courses. This was the area covered by the Vocational Training Act. On the non-vocational side of adult education Folk high schools, the Volksbildungsheime, consumer's leagues, institutions for workers' education, Christian education and civic adult education 
joined together to form an umbrella organization in 1950. In the self-image of these groups, adult education was meant to serve individual perfection and the community rather than be profit-making or geared towards professional careers (SVEB 1955).

In 1944, a powerful player appeared in Switzerland dedicated entirely to adult education as a form of leisure activity and pursuing no monetary interests; it was called the Migros Club Schools (OECD 2003, p. 61, 203). It had no qualms about seeing adult education as a consumer good like any other. For decades, the offers were cross-subsidized through the profits of the parent company and were thus able to offer massively cheaper courses compared with other private for-profit providers. By joining the umbrella organization for adult education directly, the Migros Club Schools underlined their claim not to profit from the educational needs of the population (Link 1955).

The second player, which is more difficult to classify, is the Swiss Commercial Association, founded as early as 1873 and one of the most important providers of continuing vocational training in Switzerland. Nevertheless, it also joined the umbrella organization for adult education directly and in this context emphasized its commitment to general education (Galliker 1955).

The first critical juncture was the shift towards more vocational offerings by providers of general adult education as well as the national continuing education association SVEB. The Migros Club Schools started their adult education programme with internal domestic courses during World War II and then quickly expanded their portfolio with languages, very successful arts and crafts courses and other leisure activities (Sarno 2010). From 1970 on, a shift towards CVET took place, which was accompanied by a professionalization strategy and increased coordination of course offerings. The courses were redesigned, the subjects were redefined, the demands on lecturers were clarified, the production of teaching materials was promoted, the courses were systematically evaluated and the participants were surveyed. However, the opening up towards CVET was only one aspect of the repositioning of the Migros Club Schools. At the same time, courses on psychology and social support, on a range of sports and on other non-career related subjects were established, thus making the programme extremely diverse (Link 1950; Migros-GenossenschaftsBund 1969; König 1977).

Within the national continuing education association SVEB, there were repeated disputes in the 1960s about whether to accept profit-oriented adult education providers. Politically, the umbrella organization SVEB urged that adult education be developed as part of the education system (SVEB 1970). Like the Migros Club Schools, SVEB now turned its attention to the relationship between general and vocational adult education and also sought exchange with the private sector (SVEB 1972). Providers for the continuing education of owners of small and medium-sized enterprises and the professional training of skilled workers also became members (SVEB 1976).

The small public contribution that subsidized the administration of SVEB came mainly from two sources: the cultural policy foundation Pro Helvetia opened by the federal government and the intercantonal body of the ministers of education. Further ad hoc individual grants could then be used to finance other individual concerns. Much more significant were the funds in the CVET area that subsidized up to $40 \%$ 
of course costs. However, this only applied to those courses that were covered by the Vocational Training Act. This excluded not only non-vocational adult education, but also the social, pedagogical and medical professions since training was not regulated at federal level in these areas (Amberg 1984; SVEB 1976).

\section{A new political agenda}

The trade unions hardly knew how to capitalize on this shift. In the 1970s and 1980s, they were unable to enforce their general demands for educational leave or the right to continuing education and retraining (Schlienger 1975; Schweizerischer Gewerkschaftsbund 1987). However, it seemed to be possible within the framework of collective labour agreements. In 1972, Switzerland's largest trade union succeeded in ensuring that for the engineering industry at least, employee representatives could take paid educational leave. Since 1993, this has applied to all employees in this sector (SMUV 2004, p. 42). Numerous other collective employment agreements for different sectors also regulated further training, albeit in varying degrees of detail (SECO 2003; Trampusch and Eichenberger 2012).

In a less obvious way, trade union positions had a lasting influence on the political economy of adult education in Switzerland. However, this was only possible because a part of the private sector was pushing in the same direction and because the negotiations in this case did not go through the established corporatist institutions. Until the 1970s the discussion on CVET in Switzerland was driven primarily by the economic boom. The two oil crises and the structural change that followed in Switzerland changed the whole landscape of adult education. The new qualification requirements resulting from electronic data processing and rapid technological change seemed to make flexibility and lifelong learning, to which private and state actors were now committed, a necessity (Sacchi et al. 2005; Gugerli and Tanner 2012; Büchel et al. 2020).

The government responded to the challenges posed by the new technologies with a series of impulse programs, each of which was associated with funding in the area of continuing vocational education and training. The first initiatives were pushed forward by a former trade unionist who, as a government delegate, was responsible for negotiations with the various stakeholders. This was a novelty in Switzerland, as business associations were usually closely involved with the liberal minded national economic authorities and were therefore able to get their people into these positions (Jacob 1983; Straumann 2001). In Switzerland, there was no change from a Keynesian to a neoliberal economic and social policy. Rather, approaches based on strong central planning had hardly any lobby in Switzerland, even in the boom decades. Radical federalism, pronounced corporatism and economic liberalism or strong anticommunism made interventionist policies hardly an option even before the two oil crises (Speich Chassé 2016). What can be traced, however, is that in Switzerland, as in other countries, there was a new interventionist agenda in questions of technological development that challenged the established political economy in many areas. The successes of the USA and Japan in the field of microchip technology seemed 
to call for concerted action in technological research, development and qualification (Straumann 2001).

Thus, there was a conflict in Switzerland between the still rigid liberal minded economic representatives and those who advocated a more interventionist policy, i.e., direct public investment in research, development and qualification of skilled workers. Vocational adult education benefited from this. In October 1978, the Swiss government approached the two chambers of parliament with a programme designed to respond to the consequences of the first oil crisis. Part of this very disparate initiative was aimed at further training in the field of information technology. A socalled software school was to be temporarily supported from the funds (Mey 1982). The new governmental approach generated strong protests on the part of employers. At the same time, conflicts arose within the business associations and between the companies. Some companies were already directly affected by technological change, while others saw no fundamental need for reform of the established Swiss political economy of skill formation and technology development (Jucker 1980a, 1980b; Mey 1982). For this reason, the temporary character of impulse programmes was an important concern of the government. However, as early as 1982, the next initiative was decided upon. It was to last six years and included the establishment of a continuing education institution in the field of business informatics (Schweizerischer Bundesrat 1982). A third impulse programme, designed to run for five years and adopted in 1985, was aimed primarily at IT training at universities, but also contained individual measures to promote continuing education. At the higher technical schools, for example, the in-service training of teaching staff was to be financially supported. A further focus was on further training of engineers (Schweizerischer Bundesrat 1986).

At the beginning of the 1990s, the various impulse programmes resulted in a final "Continuing education initiative", which continued to have a clear connection to technological change, but was now also intended to promote the expansion of postgraduate continuing education at Switzerland's universities (Angst 1991). The funds could be allocated to the cantons, employers and employee associations and also to public or private non-profit providers. The addressees were skilled and unskilled workers, women and foreigners, persons wishing to re-enter working life. In addition, the measures were meant to promote the basic willingness of the population to undergo further training (Schmitter 1992). Even if the universities were initially sceptical, this project represented a central thrust for the institutionalization of post-tertiary continuing education. The subsequent development of modularized programmes (Certificate of Advanced Studies, Diploma of Advanced Studies and Master of Advanced Studies) has led to a nationwide consolidation of adult education programmes at universities in Switzerland (Gonon 2019). The continuing education initiative ended when the European Union proclaimed the Year of Lifelong Learning, which was also celebrated in Switzerland with a so called "learning festival" which took place in all Swiss cantons (Dohmen 1997). 


\section{Cantonal legislation, soft power and educational lobbyism}

Since the middle of the 20th century, at least continuing vocational education in Switzerland did not have a pure market character. Rather, it was integrated into the established and finely balanced corporatism and was also partly regulated and funded through the National Vocational Training Act. As the common understanding of vocational education and training became more fluid and a new paradigm of lifelong learning emerged in Europe (Centeno 2011), non-vocational adult education increasingly moved into the focus of centralistic government initiatives. The impulse programmes and the rapid technological change with regular new qualification requirements, had partly softened the rigid position of employers, but without fundamentally calling into question the traditional political economy of skill formation in Switzerland. Technological change seemed to call for centralist interventions and direct investment in private sector research, development and continuing vocational education and training. At the same time, concerns remained on the business side about greater centralization in education policy. In Switzerland, the employers and the liberal discourse remained powerful. The government had to ensure that the individual programmes were always only "impulses" and not sustainable structural programmes. Continuing education was meant to remain with individuals, business associations and companies. This also continued to be the position of the federal authorities (EVD 2009).

The solution for these contradictory developments was the formalization of adult education, modularization and the establishment of so-called qualification systems. This was not initially promoted by the state authorities, but by the national continuing education association SVEB, which was committed to the professionalization of staff and the stronger formal structuring of the course landscape. This development started as early as the 1960s and was continuously reinforced until the end of the century (Rohrer and Sgier 1995, 1996).

However, education was to remain a matter for the cantons, as the population repeatedly decided in the 20th century. A constitutional amendment, which included an article on education and also defined adult education as a federal matter, was rejected in a referendum in 1973. The same happened in 1986 and 1994 with two referenda that were to give constitutional status to cultural promotion and that would also have covered general adult education (Weber 2007). The situation was different for continuing vocational education and training, which was even strengthened by the 1978 revision of the law. Remarkably, this revision introduced a broader understanding of adult vocational education and training, which included measures dedicated to improving general education (Rohrer and Sgier 1995, 1996).

At the cantonal level, at least some developments took place. By 1985, articles on adult education were included in the school laws in four cantons. In two other cantons they were mentioned in the laws on cultural matters. Some cantons set up specialized departments and consultative boards or appointed experts in matters relating to adult education. In 1992, the Canton of Berne passed its own Adult Education Act. However, this new cantonal law excluded all ideologically bound providers (trade unions, churches) from funding (Rohrer and Sgier 1995, 1996). 
The establishment of qualification systems was thus first promoted by the private umbrella association SVEB, not by the authorities and not by employer and business associations or trade unions. In the late 1960s, SVEB was responsible for a study on "Success in adult education" (SVEB 1969). This laid the foundation for various attempts at formalization and professionalization over the following decades, which the federal authorities were then able to follow up directly. Since the late 1960s, SVEB has also been working to professionalize its staff, commission studies and improve documentation. Since 1970, SVEB has trained lecturers in adult education and also awarded a certificate. The whole effort was at this point under the motto of efficiency in adult education (SVEB 1976). In 1994, SVEB issued a two-stage qualification procedure to qualify adult educators (Schläfli and Sgier 2008).

The SVEB lobbied continuously for stronger state regulation and public funding of adult education and submitted proposals for laws and entire packages of measures. For the second time in 1983, the association submitted its "Proposals for laws to promote adult education" (SVEB 1983). While the federal authorities continued to be reticent about subsidizing general continuing education, they were now committed to improving knowledge about participation in continuing education. The state authorities contributed to this formalization of adult education by increasingly commissioning empirical surveys from which the need for political or private action could then be derived. In 1987, they commissioned the first national survey on the "continuing education behaviour of the Swiss population" (Dal Maso and Locher 1989).

In 1994 a working group developed a concept for continuing vocational training using a modular system, which was subsequently tested. Following a petition in the national parliament, the pilot project was intended to provide a basis for subsequent legal regulation. The federal state boards also planned to create a central body to coordinate and control the activities of the module suppliers (Schweizerischer Bundesrat 1996). After a phase of great modular euphoria, the organization of the federal authorities was reformed and the will to shape the future weakened. There was also resistance from one of the largest and most influential business associations, which opposed more state regulation in the area of the CVET. Although the principle of modularization was widely accepted, this could not be implemented without substantial support from the federal authorities (Gonon 1998; Wettstein 2005).

This gap was filled by the extremely successful quality label "eduQua", which was developed at the end of the millennium by the Federal Board for Vocational Education and Training as well as the umbrella association SVEB. It was officially launched after the turn of the millennium. The aim of the label is to make the continuing education market more transparent both for clients and for the allocation of public funds. It is aimed at all adult education providers, both vocational and general (Sroka 2005).

\section{The national continuing education law: a critical juncture?}

In 2017, a national law on continuing education came into force in Switzerland. In a small, decentralized state, which to date has 26 cantonal school laws. However, 
the new regulation is only a framework law which has little funding of its own. The regulations on questions of adult education in 80 other national laws continue to remain in force. The primary aim of the law is not to create new areas of state support as to coordinate the governance of continuing education at federal and cantonal level. The law lays down principles, but hardly makes any comments on specific issues. The main addressees are the federal state boards and the cantons. The law applies to all special laws containing regulations on adult education. The substance of these special laws is therefore not affected (Schweizerischer Bundesrat 2013; Schläfli and Sgier 2014). However, one section of the law is dedicated to the provision of basic skills for adults (Schweizerischer Bundesrat 2014, Art. 13-16).

In a referendum in 2006, for the first time in Swiss history a general article on educational matters was included in the constitution. Previously the state only had competence in vocational education and training. As a result, a separate continuing education law became necessary. The new regulations were organized as a framework law and contained only an absolute minimum programme (Schweizerischer Bundesrat 2013).

Thus, the law sanctions the already established structure. However, the national but private continuing education association SVEB, can directly assume tasks under state responsibility. In application of Article 12 of the Continuing Education Act, SVEB is now able to conclude multi-year performance agreements with the State Secretariat for Education, Research and Innovation SERI (SVEB 2016). The models and certificates developed earlier by adult education organizations help as highly formalized instruments to advance the development of qualification systems. Since 2018, the SVEB holds the responsibility for the eduQua label. The association also hosts the eduQua office. Government funding for SVEB is used to further develop adult education, to conduct studies, to set up think tanks or carry out work in the field of quality assurance (SVEB 2017).

One can see from the law that there is a balancing act between not calling the established structure into question and yet taking the constitutional amendment into account. The law explicitly highlights personal initiative and employability as central features of the legal framework for continuing education in Switzerland. Claims and obligations are not formulated, but softer intentions are articulated instead. Before a section comments on "equal opportunities", an article clarifies: "The individual person bears the responsibility for his or her continuing education" (Schweizerischer Bundesrat 2014, Art. 5.1).

In Switzerland, continuing education is not simply regulated via the market. At least in the case of vocational adult education, it is strongly structured by collective skill formation, which also determines initial vocational education and training. Historically, state subsidies were possible at an early stage and the professional associations are still involved in this area today. At the same time, the market for continuing education was for a long time dominated by one provider, Migros Club Schools, which was founded by a company and was private. At the same time, the courses offered by Migros Club Schools systematically undercut market prices because they were partially cross-financed by the parent company.

Finally, developments are hard to understand if the educational lobbyism of SVEB, the umbrella organization for adult education, is not included. For a long 
time, this was neglected by the federal authorities. Nevertheless, SVEB developed highly formalized concepts for professionalization and quality assurance with great expertise, which the federal authorities were later able to follow up. With the impulse programmes seen since the late 1970s, the government repeatedly broke with its liberal regulatory agenda. The federal law on continuing education and the subsequent ordinances and service agreements were able to follow on from this and thus did not have to install a completely new regulatory practice. The law was therefore, as far as can be assessed at present, not a critical juncture. The decisive course was set earlier.

Open Access This article is licensed under a Creative Commons Attribution 4.0 International License, which permits use, sharing, adaptation, distribution and reproduction in any medium or format, as long as you give appropriate credit to the original author(s) and the source, provide a link to the Creative Commons licence, and indicate if changes were made. The images or other third party material in this article are included in the article's Creative Commons licence, unless indicated otherwise in a credit line to the material. If material is not included in the article's Creative Commons licence and your intended use is not permitted by statutory regulation or exceeds the permitted use, you will need to obtain permission directly from the copyright holder. To view a copy of this licence, visit http://creativecommons.org/licenses/by/4.0/.

\section{Literature}

Amberg, H.-U. (1984). Eigenheiten der schweizerischen Erwachsenenbildung. In H.-U. Amberg, et al. (Ed.), Thema Erwachsenenbildung: Versuche zur Begriffserklärung in der Schweiz (pp. 13-19). Frankfurt a.M.: Pädagogische Arbeitsstelle des Deutschen Volkshochschul-Verbandes.

Angst, K. (1991). Die Weiterbildungsoffensive des Bundes. Sinn und Grenzen des staatlichen Engagements im quartären Weiterbildungsbereich. In H. Giger (Ed.), Bildungspolitik im Umbruch: Staatsmonopol in der Weiterbildung? (pp. 263-272). Zurich: Neue Zürcher Zeitung.

Bonoli, L. (2019). Where are the trade unions? Some insights into the historical evolution of the Swiss VET system. In M.F. Fernando \& M. J. Chisvert-Tarazona (Eds.), Pedagogical concerns and market demands in VET. Proceedings of the 3rd Crossing Boundaries in VET conference, Vocational Education and Training Network (VETNET). (pp. 137-142). Valencia: Zenodo.

Büchel, K., Geiss, M., \& Hägi, L. (2020). Berufsbildung, Konjunktur und Arbeitsmarkt. In I. Brühwiler, L. Criblez, C. Crotti, M. Helfenberger \& M. Hofmann (Eds.), Bildungsgeschichte der Schweiz - 19. und 20. Jahrhundert. Zurich: Chronos.

Busemeyer, M.R., \& Trampusch, C. (2012). The comparative political economy of collective skill formation. In M. R. Busemeyer \& C. Trampusch (Eds.), The political economy of collective skill formation (pp. 3-40). Oxford: Oxford University Press.

Capoccia, G. (2016). Critical junctures. In O. Fioretos, T. G. Falleti \& A. Sheingate (Eds.), The oxford handbook of historical institutionalism (pp. 95-108). Oxford: University Press.

Centeno, V. (2011). Lifelong learning: a policy concept with a long past but a short history. International Journal of Lifelong Education, 30(2), 133-150. https://doi.org/10.1080/02601370.2010.547616.

Desjardins, R. (2017). Political economy of adult learning systems: comparative study of strategies, policies and constraints. London: Bloomsbury Academic.

Dohmen, G. (1997). Das Jahr des lebenslangen Lernens - Was hat es gebracht? In H. Faulstich-Wieland, et al. (Ed.), REPORT Literatur- und Forschungsreport Weiterbildung (Vol. 39, pp. 10-26).

EVD - Eidgenössisches Volkswirtschaftsdepartement (2009). Bericht des EVD über eine neue Weiterbildungspolitik des Bundes in Zusammenarbeit mit dem Eidgenössischen Departement des Inneren. Berne: EVD.

Galliker, A. (1955). Erwachsenenbildung im schweizerischen Kaufmännischen Verein. In SVEB (Ed.), Erwachsenenbildung in der Schweiz (pp. 151-159). Zurich: Artemis.

Geiss, M. (2016). Sanfter Etatismus: Weiterbildungspolitik in der Schweiz. In L. Criblez, C. Rothen \& T. Ruoss (Eds.), Staatlichkeit in der Schweiz: Regieren und Verwalten vor der neoliberalen Wende (pp. 219-246). Zurich: Chronos.

Gonon, Ph (1998). Modularisierung als reflexive Modernisierung. In D. Euler (Ed.), Berufliches Lernen im Wandel - Konsequenzen für die Lernorte? (pp. 305-321). Nürnberg: Institut für Arbeitsmarkt- und Berufsforschung. 
Gonon, Ph (2019). Zur Legitimität von Hochschulweiterbildung in der Schweiz - Zwischen Wissenschaftsund Arbeitsmarktorientierung. In C. Imdorf, R. J. Leemann \& P. Gonon (Eds.), Bildung und Konventionen. Die „Economie des conventions“ in der Bildungsforschung (pp. 375-403). Wiesbaden: Springer VS.

Gugerli, D., \& Tanner, J. (2012). Wissen und Technologie. In P. Halbeisen, M. Müller \& B. Veyrassat (Eds.), Wirtschaftsgeschichte der Schweiz im 20. Jahrhundert (pp. 265-316). Basel: Schwabe.

Jacob, A. (1983). Die Bedeutung der Impulsprogramme für die Schweizer Wirtschaft: positive Bilanz. Schweizer Ingenieur und Architekt, 46(83), 1104-1105.

Jessop, B. (2011). Rethinking the diversity of capitalism: varieties of capitalism, variegated capitalism, and the world market. In G. Wood \& C. Lane (Eds.), Capitalist diversity and diversity within capitalism (pp. 209-237). London: Routledge.

Jucker, W. (1980a). Beziehungen zwischen Schule, Wirtschaft und Technik. Gewerkschaftliche Rundschau, $72(1), 1-10$.

Jucker, W. (1980b). Wirtschaftliche und soziale Auswirkungen der Mikroelektronik und elektronischen Datenverarbeitung. Gewerkschaftliche Rundschau, 72(3), 83-95.

König, J. (1977). Entwicklungstendenzen in der schweizerischen Erwachsenenbildung, verglichen anhand sozialisationstheoretischer und bildungstheoretischer Gesichtspunkte. Zurich: Juris.

Link, P. (1950). Die Klubschule Migros. Zurich: s.n.

Link, P. (1955). Klubschule Migros. In SVEB (Ed.), Erwachsenenbildung in der Schweiz (pp. 103-107). Zurich: Artemis.

Dal Maso, G., \& Locher, J. (1989). Weiterbildung in der Schweiz: Auswertung einer Umfrage. Die Analyse von Weiterbildungsdaten: eine spezielle Auswertung der Untersuchung „Das psychologische Klima der Schweiz (PKS) “ der Demoskop AG. Berne: Bundesamt für Bildung und Wissenschaft.

Mey, H. (1982). Die Software-Schule Schweiz. Hasler-Mitteilungen, 41(2), 21-27.

Migros-Genossenschafts-Bund (1969). 25 Jahre Klubschule Migros. Zurich: Migros-GenossenschaftsBund.

OECD (2003). Tertiary education in Switzerland: reviews of national policies for education. Paris: OECD.

Peck, J., \& Theodore, N. (2007). Variegated capitalism. Progress in Human Geography, 31(6), 731-772.

Rees, G. (2013). Comparing adult learning systems: an emerging political economy. European Journal of Education, 48(2), 200-212. https://doi.org/10.1111/ejed.12025.

Rohrer, C., \& Sgier, I. (1995). Erwachsenenbildungs-Politik in der Schweiz: Strukturen, Rechtsgrundlagen, Tendenzen Ein Forschungsbericht. Zurich: SVEB.

Rohrer, C., \& Sgier, I. (1996). Switzerland. International Review of Education, 42(1-3), 131-150.

Sacchi, S., Salvisberg, A., \& Buchmann, M. (2005). Long-term dynamics of skill demand in Switzerland from 1950-2000. In H. Kriesi, P. Farago, M. Kohli \& M. Zarin-Nejadan (Eds.), Contemporary Switzerland: revisiting the special case (pp. 105-134). New York: Palgrave Macmillan.

Sarno, S. (2010). Die Entstehung der Migros Klubschule (=Lizenziatsarbeit der Philosophischen Fakultät der Universität Zürich). Zurich: University of Zurich.

SBFI - Staatssekretariat für Bildung, Forschung und Innovation SBFI (2019). Indikatoren zum Monitoring des Weiterbildungsgesetzes. Bern: SBFI. https://www.sbfi.admin.ch/dam/sbfi/de/dokumente/ 2019/07/indikatoren-webig.pdf.download.pdf/indikatoren_webig_d.pdf

Schläfli, A., \& Sgier, I. (2008). Porträt Weiterbildung Schweiz. Vol. 2. Bielefeld: W. Bertelsmann.

Schläfli, A., \& Sgier, I. (2014). Weiterbildung in der Schweiz (3rd edn.). Bielefeld: W. Bertelsmann.

Schlienger, U.W. (1975). Bildungsurlaub: Einflüsse, Meinungen und Argumentationen. Onex Genève: Selbstverlag.

Schmitter, Ch (1992). Die Weiterbildungsoffensive (WBO) im Berufsbildungsbereich - eine Zwischenbilanz. Volkswirtschaft, 2(92), 40-43.

Schweizerischer Bundesrat (1932). Verordnung Nr. 1 vom 23. Dezember 1932 zum Bundesgesetz über die berufliche Ausbildung. http://www.edudoc.ch/static/infopartner/mediothek_fs/bis_1997/010356.pdf. Accessed April 30, 2020.

Schweizerischer Bundesrat (1928). Botschaft des Bundesrates an die Bundesversammlung zum Entwurf eines Bundesgesetzes über die berufliche Ausbildung vom 9. November 1928. Bundesblatt, 1928(46), $725-798$.

Schweizerischer Bundesrat (1962). Botschaft des Bundesrates an die Bundesversammlung zum Entwurf eines Bundesgesetzes über die Berufsbildung vom 28. September 1962. Bundesblatt, 1962(4), 885-980.

Schweizerischer Bundesrat (1982). Botschaft über Massnahmen zur Förderung der technologischen Entwicklung und Ausbildung vom 3. Februar 1982. Bundesblatt, 1982(17), 1263-1320. 
Schweizerischer Bundesrat (1986). Botschaft über Sondermassnahmen zugunsten der Ausbildung und Weiterbildung sowie der Forschung in der Informatik und den Ingenieurwissenschaften vom 2. Dezember 1985. Bundesblatt, 1986(5), 321-383.

Schweizerischer Bundesrat (1996). Bericht des Bundesrates über die Berufsbildung (Bundesgesetz über die Berufsbildung). Bern: Schweizerischer Bundesrat. http://www.panorama.ch/pdf/bba1620b.pdf

Schweizerischer Bundesrat (2013). Botschaft zum Bundesgesetz über die Weiterbildung vom 15. Mai 2013. Bundesblatt, 2013, 3729-3804.

Schweizerischer Bundesrat (2014). Bundesgesetz über die Weiterbildung (WeBiG) vom 20. Juni 2014. https://www.admin.ch/opc/de/classified-compilation/20141724/index.html.

Schweizerischer Gewerkschaftsbund (1987). III. Die Situation in der Schweiz: Vor- und Nachteile des Weges über die Gesetzgebung, resp. den Gesamtarbeitsvertrag. Gewerkschaftliche Rundschau, 79(5), $178-184$.

SECO - Staatssekretariat für Wirtschaft (2003). Bericht des Bundesrates zur Weiterbildung im Arbeitsrecht. Berne: SECO.

SMUV - Gewerkschaft Industrie, Gewerbe, Dienstleistungen (2004). Keinen Schritt umsonst getan: Blicke auf die Gewerkschaft SMUV, 1970-2000. Baden: hier + jetzt.

Speich Chassé, D. (2016). Gab es in der Schweiz eine neoliberale Wende? Ein Kommentar. In L. Criblez, C. Rothen \& T. Ruoss (Eds.), Staatlichkeit in der Schweiz. Regieren und verwalten vor der neoliberalen Wende (pp. 369-384). Zurich: Chronos.

Sroka, W. (2005). Evaluation und Qualitätsmanagement in Weiterbildungseinrichtungen der Schweiz. Berlin: DIPF.

Straumann, T. (2001). Rezession, Technologiepolitik und Risikokapital: das Scheitern der Innovationsrisikogarantie, 1985. In H.-J. Gilomen, R. Jaun, M. Müller \& B. Veyrassat (Eds.), Innovationen: Voraussetzungen und Folgen - Antriebskräfte und Widerstände (pp. 403-419). Zurich: Chronos.

SVEB - Schweizerische Vereinigung für die Erwachsenenbildung (1955). Erwachsenenbildung in der Schweiz. Zurich: Artemis.

SVEB - Schweizerische Vereinigung für die Erwachsenenbildung (1970in). Bildungsreform ja - aber auch für Erwachsene, in der vorliegenden Fassung beschlossen an der 19. ordentlichen Delegiertenversammlung der Schweiz. Vereinigung für Erwachsenenbildung, am 20. Juni 1970 in Männedorf, in der vorliegenden Fassung beschlossen. Zurich: SVEB.

SVEB - Schweizerische Vereinigung für die Erwachsenenbildung (1972). Koordination von allgemeiner und beruflicher Weiterbildung? Bericht einer Umfrage. Zurich: SVEB.

SVEB - Schweizerische Vereinigung für Erwachsenenbildung (1969). Über den Erfolg in der Erwachsenenbildung: Empirische Basisstudie zum Problem der Erfassung des Bildungserfolges. Zurich: SVEB.

SVEB - Schweizerischen Vereinigung für Erwachsenenbildung (1976). Erwachsenenbildung in der Schweiz. Frauenfeld: Huber.

SVEB - Schweizerischen Vereinigung für Erwachsenenbildung (1983). Vorschläge für Gesetze zur Förderung der Erwachsenenbildung (2nd edn.). Zurich: SVEB.

SVEB - Schweizerischer Verband für Weiterbildung (2016). Jahresbericht. Zurich: SVEB. https://alice. ch/de/sveb/organe/dv-dokumente/.

SVEB - Schweizerischer Verband für Weiterbildung (2017). Jahresbericht. Zurich: SVEB. https://alice. ch/de/sveb/organe/dv-dokumente/.

Thelen, K. A., \& Steinmo, S. (1992). Historical institutionalism in comparative politics. In S. Steinmo, K. A. Thelen \& F. Longstreth (Eds.), Structuring politics: historical institutionalism in comparative analysis (pp. 1-32). Cambridge: Cambridge University Press.

Trampusch, C., \& Eichenberger, P. (2012). Skills and industrial relations in coordinated market economies - continuing vocational training in Denmark, the Netherlands, Austria and Switzerland. British Journal of Industrial Relations, 50(4), 644-666. https://doi.org/10.1111/j.1467-8543.2011.00864.x.

Weber, K. (2007). Berufliche Weiterbildung in der Schweiz. Struktur und Steuerung. In C. Crotti (Ed.), Pädagogik und Politik. Historische und aktuelle Perspektiven. Festschrift für Fritz Osterwalder (pp. 295-316). Berne: Haupt.

Weber, K., \& Wittpoth, J. (1999). Discourse, structure and practice of continuing education: a comparison between Switzerland and Germany. International Review of Education, 45(5), 547-560. https://doi. org/10.1023/A:1003891327534.

Wettstein, E. (2005). Modularisierung im Berufsbildungssystem der Schweiz. Schweizerische Zeitschrift für Bildungswissenschaften, 27(2), 157-174.

Publisher's Note Springer Nature remains neutral with regard to jurisdictional claims in published maps and institutional affiliations. 